\title{
Performance and Text in Ancient Greece
}

\section{Citation}

Nagy, Gregory. 2009. Performance and Text in Ancient Greece. In The Oxford Handbook of Hellenic Studies, ed. G. Boys-Stones et al., 417-431. Oxford and New York: Oxford University Press.

\section{Published Version}

doi:10.1093/oxfordhb/9780199286140.013.0037

\section{Permanent link}

http://nrs.harvard.edu/urn-3:HUL.InstRepos:15549937

\section{Terms of Use}

This article was downloaded from Harvard University's DASH repository, and is made available under the terms and conditions applicable to Other Posted Material, as set forth at http:// nrs.harvard.edu/urn-3:HUL.InstRepos:dash.current.terms-of-use\#LAA

\section{Share Your Story}

The Harvard community has made this article openly available.

Please share how this access benefits you. Submit a story.

Accessibility 


\section{Performance and text in ancient Greece}

\section{Gregory Nagy}

[[This essay is an expanded online version (2010) of an original printed version that appeared as Chapter 34 in The Oxford Handbook of Hellenic Studies, ed. G. Boys-Stones, B. Graziosi, P. Vasunia (Oxford: Oxford University Press 2009) 417-431. In this expanded version, the original page-numbers of the printed version are indicated within braces ("\{" and " $\}$ "). For example, " $\{417 \mid 418\}$ " indicates where p. 417 of the printed version ends and p. 418 begins.]]

The terms performance and text, as a pair, cannot be considered the equivalent of another pair of terms, orality and literacy. Still, there is a link between performance and orality, matching the obvious link between text and literacy. In what follows, I propose to consider these matching links.

The concept of orality stems from ethnographic descriptions of oral poetry in particular and of oral tradition in general (Nagy 2001). A basic work on these two concepts is The Singer of Tales, by Albert B. Lord (1960; posthumous new ed. 2000, with new introduction by Mitchell and Nagy). This book documents the research of Lord's teacher, Milman Parry, on oral traditions in the former Yugoslavia, 1933-35 (collected papers, Parry 1971). Parry was a professor of ancient Greek, seeking new answers to the so-called Homeric Question. Basically, the "question" came down to this: were the Homeric Iliad and Odyssey composed with or without the aid of writing? Parry's project, the comparing of Homeric poetry with the living oral traditions of South Slavic heroic poetry, led him to conclude that the Homeric texts were indeed the products of oral composition. Parry's research was continued by his student, Albert Lord, whose Singer of Tales represents the legacy of their combined efforts.

The cumulative work of Parry and Lord is generally considered to be the single most successful solution to the Homeric Question, though the debate among Classicists continues concerning the contingencies of Homeric composition. The ultimate success of Parry and Lord, however, can best be measured by tracking the applications of their methods to a wide range of literatures and preliteratures beyond the original focus on ancient Greek oral poetry (Mitchell and Nagy 2000). These applications $\{417 \mid 418\}$ have led to the formulation of an essential idea that extends to all oral traditions, both poetry and prose. The idea is this: oral traditions formed the basis of literary traditions.

There had been earlier formulations of this idea, but Parry and Lord were the first to perfect a systematic way of comparing the internal evidence of living oral traditions, as observed in their fieldwork, with the internal evidence of literary traditions. It is primarily their methodology that we see reflected in the ongoing academic usage of such terms as orality and oral theory. (On the pitfalls of using the term oral theory, see Nagy 1996b:19-20.) 
For Parry and Lord, the histories of literary and oral traditions, of literatures and preliteratures, were interrelated. Accordingly, Lord would even speak of oral literature (Lord 1995, especially chapter 8 ). Further, Lord developed the comparative study of oral and literary traditions into a new branch of Comparative Literature (Guillén 1993:173-179; Mitchell and Nagy 2000:xvii).

Attested in a wide variety of societies, from prehistoric times all the way into the present, oral traditions can most broadly be described as verbal systems of expression combining performance and composition.

Here we come to the element of performance, which is clearly an aspect of oral traditions. But performance in and of itself does not define any oral tradition. Not all performance involves oral tradition, even if all oral tradition involves performance. It is the relationship of performance to composition that leads to a definition of any given oral tradition. As we consider the many various oral traditions of the world, we find many variations in this relationship: besides the basic category of the performing composer who is at the same time the composing performer, we need to consider such additional categories as (1) the reperforming composer, (2) the recomposing performer, (3) the reperformed composer, and even (4) the recomposed performer (Nagy 1996a).

The last two of these four categories are exemplified by the traditions of performing Homeric poetry in Athens during the classical period of the fifth century BCE. In this historical context, Homer is seen as the reperformed composer of the Iliad and Odyssey as performed by rhapsoidoi 'rhapsodes' at the seasonally recurring festival of the Panathenaia in Athens (Nagy 2002). In the ongoing process of recurring performances, Homer's very identity is recomposed to make him a spokesman of the Athenians (Nagy 2008/2009).

In this classical period, Homeric poetry is static or fixed, not fluid. This fixity has led to the inference that this poetry had always been a written text. The term written text, however, is too imprecise for describing what had been a process of gradual fixation in the ongoing tradition of performing Homeric poetry. This process can be described in terms of a progression from transcript to script. By transcript I mean the broadest possible category of written text: a transcript can be a record of performance, even an aid for performance, but not the equivalent of performance (Nagy 1996b:34-36, 65-69). We must distinguish a transcript from an inscription, which can traditionally refer to itself in the archaic period as an $\{418 \mid 419\}$ equivalent of performance (Nagy 1996b:34-36). As for script, I mean a narrower category, where the written text is a prerequisite for performance (Nagy 1996b:32-34).

In considering such categories, we need to ask what happens when oral traditions become written traditions - or when oral traditions come into contact with pre-existing written traditions. In the history of scholarship on this question, the work of Parry and Lord is 
pivotal. Their fieldwork on the living oral traditions of the former Yugoslavia gave them an opportunity to test the living interactions of oral and literary traditions. They observed that the prestige of writing as a technology, and of the culture of literacy that it fostered, tended to destabilize the culture of oral traditions - in the historical context they were studying. What they observed, however, was strictly a point of comparison with other possible test cases, not some kind of universalizing formulation (Mitchell and Nagy 2000:xiii). For example, Lord himself makes it clear in his later work that there exist many cultures where literary traditions do not cause the destabilization of oral traditions and can even coexist with them (Lord 1991; see also especially Lord 1986). In general, the textualization or Verschriftung of any given oral tradition needs to be distinguished from Verschriftlichung - that is, from the evolution of any given culture of literacy, any given Schriftlichkeit (Oesterreicher 1993).

For Parry and Lord, the opposition of literacy and orality - of Schriftlichkeit and Mündlichkeit - is a cultural variable, not a universal. Moreover, their fieldwork experiments led them to think of literacy and orality as cognitive variables as well (Mitchell and Nagy 2000:xiv).

Despite this stance of Parry and Lord, it has been claimed - many times and in many ways - that the Parry-Lord "theory" is founded on a hard-and-fast distinction between orality and literacy. These claims stem from unfamiliarity with the ethnographic dimension of Parry's and Lord's work, and, more generally, from ignorance about the observable mechanics and esthetics of oral traditions (Mitchell and Nagy 2000:xiv).

Humanists today may be tempted to romanticize literacy as the key to "literature," often equated with "high" culture (on empirical approaches to distinctions between "high" and "low" culture, as occasionally formalized in distinctions between oral and written traditions, see Bausinger 1980). And yet, the only universal distinction between oral and literary traditions is the historical anteriority of the first to the second. Beyond this obvious observation, it is pointless to insist on any universalizing definitions for the "oral" of "oral tradition." "Oral tradition" and "oral poetry" are terms that depend on the concepts of "written tradition" and "written poetry." In cultures that do not depend on the technology of writing, the concept of "orality" is meaningless (Lord 1995:105n26). From the standpoint of comparative ethnography, "Written is not something that is not oral; rather it is something in addition to being oral, and that additional something varies from society to society" (Nagy 1990:0\$16). The technology of writing has nothing to do with whether there can or cannot be poetics or rhetoric. Poetics and rhetoric can exist without writing.

It is needless to posit a dichotomy between orality and text in the history of Greek civilization. But the question remains: is there a dichotomy between performance and text? To find an answer, we must consider how the technology of writing relates to the production of texts. Further, we must consider the rationale behind the production of texts. 
As we are about to see, the text was meant not only for reading as we understand the phenomenon of reading. It was meant also for performance.

This formulation can be justified on the basis of observations made by Aristotle in his Poetics concerning the reading of texts. As we will see presently, these observations show that the ancient Greeks, including Aristotle himself, regarded reading as a reenactment of live speech. Such a sense of reenactment was driven by their writing system.

When Aristotle in the Poetics (1456b20-38) speaks about syllables and about the consonants and vowels that $\{419 \mid 420\}$ delimit them, he is doing far more than that. By hindsight, we can say he is demonstrating a remarkably accurate linguistic understanding of the sound system or phonology of the Greek language as spoken in his time, the fourth century BCE. Just as remarkable is the phonological accuracy of the writing system inherited by Aristotle and his contemporaries in reproducing the language that went into the texts they produced. That system is what we know as the Greek alphabet, which had been derived many centuries earlier from the Phoenician alphabet. The ancient Greek text, as produced by way of alphabetic writing, was a most accurate sound-recording of the ancient Greek language.

From the very earliest times, the Greek alphabet excelled in phonological accuracy. The same cannot be said about the earlier Phoenician alphabet from which it was borrowed. The writing system of the Phoenicians, in the course of its evolution, had dispensed with the representation of vowels. We see the same principle in the writing system of Hebrew, a language closely related to Phoenician. It was a loss of phonological accuracy for the alphabets of these two Semitic languages to dispense with vowels, but there was a compensatory gain in morphological accuracy. That is because, in both Phoenician and Hebrew morphology, the consonants in the "root" of any word were a constant while the vowels were a variable. So the morphological integrity of the individual word could be maintained by writing only the consonants in the Semitic alphabets - provided that each word was divided from the next. By contrast, in the process of borrowing the writing system of the Phoenicians, the writing system of the Greeks developed a way to represent vowels.

The historical consequences are vast. In effect, the ancient Greeks thus developed the first "pure" alphabetic system. One linguist (Gelb 1963:184) has described this development as "the last important step in the history of writing." He adds that, "from the Greek period up to the present, nothing new has happened in the inner structural development of writing." In other words, the Greek alphabet "conquered the world," since "we write consonants and vowels in the same way as the ancient Greeks did."

From one perspective, this development can be counted as a shining example of the Greek "miracle" (for an overall critique of such a way of thinking about the Greeks, see Gernet 1983). From another perspective, it is simply a contingency - or, in terms of the Greek 
language, a kairos, something that happens at the right time and at the right place. In this case, what happened is that certain consonants as pronounced in Phoenician were simply not heard in Greek. The prime example is the Phoenician consonant /\%, a "glottal stop" that was represented by the Phoenician letter \{'\} called /'ālep/. The principle is acrophonic: \{\} as in /'ālep/meaning 'ox', $\{B\}$ as in /bêt/ meaning 'house', and so on. The principle applies to this day, as when we say $\{B\}$ as in /boy/. But the consonant /'/ of the syllable /'a/ as spelled by the letter called /ālep/ in Phoenician was simply not heard by native speakers of ancient Greek, whereas the consonant $\{b\}$ of the syllable [be] as spelled by the letter called /bêt/ in Phoenician was clearly heard, as we see in the Greek letter $\{B\}$ for /bēta/. So the Greek letter $\{$ A\} for /alpha/, borrowed from the Phoenician letter \{'\} for /'ālep/, represented acrophonically the vowel /a/ of /alpha/, not the consonant /'/ of /'àlep/. The principle applies to this day, as when we say $\{A\}$ as in /apple/. Similarly, the Greek letters $\{E\}$ and $\{0\}$ for the vowels /e/ and /o/ came from Phoenician letters for the consonants $\{h\}$ and \{\} in word-initial sequences of /he-/ and /'a-/ that were heard as /e-/ and /o-/ respectively in ancient Greek. Finally, the Phoenician letter $\{\mathrm{H}\}$, pronounced as /hêt $/$, was heard as /ēta/ by speakers of East Ionian Greek dialects that had no word-initial /h-/, while it was heard as /hēta/ by speakers of other dialects; so, thanks to the loss of word-initial /h-/ in their dialect, the East Ionians gained another vowel in their alphabet - a vowel that was borrowed only later into the writing systems of other Greeks (Nagy 2008:37).

In early Greek alphabetic writing, the practice of dividing words from each other by way of blank spaces or special marks is well attested, as we see from inscriptions dating from before the classical period of the fifth century BCE. But this practice, parallel to what we find in texts written in Semitic alphabets, became obsolescent with the advent of the classical period. It was replaced by the practice of scriptio continua, which is a mode of writing that runs words together, and this practice persisted all the way through the ninth and tenth centuries $\mathrm{CE}$. From then on we see a radical shift toward the newer practice of dividing the words from each other by way of blank spaces, and this newer practice continues to this day in the editing of classical texts. So the question is, why was scriptio continua a basic feature of ancient Greek literacy for a period that covers well over a thousand years?

For the modern reader, the continuous flow of letters in scriptio $\{420 \mid 421\}$ continua, without blank spaces between words, actually impedes the cognitive flow of reading itself. We can pick out the words more readily when we see them separated from each other by blank spaces. I use here the metaphor of picking out the words because it applies to the cognitive process of reading in the ancient world as well. That is what we see, for example, from the meaning 'pick out, select' inherent in the use of legein in referring to the ancient practice of reading out loud from a text (as in Plato Theaetetus 143c and in the Attic orators). The ancient Greek reader, while reading out loud, has to pick out the words. Granted, the reader also has to pick out the overall meaning from the continuous stream of letters that are being read, but the fact is that the basic unit of meaning for readers of Greek in ancient as well as in modern times 
is still the word. So by now the question deepens: why were words run together in scriptio continua if they impeded the cognitive flow of reading?

The answer is simple: scriptio continua promoted the phonological realism of continuity in speaking or singing or reciting in ways that people really spoke and sang and recited. Stopping at the wrong place between words could impede the flow, the continuity. Stopping could only be allowed at the right place, that is, at the end of a word that coincides with the end of a phrase or a clause, with the end of a colon or a verse. That would be phonologically right. Stopping elsewhere would be phonologically wrong, ruining the rhythmic and melodic contour of the phrasing.

The systematization of when to stop and when not to stop between words is evident in some surviving ancient texts. We see a striking illustration in a set of papyri dating from the second century $\mathrm{CE}$ featuring the songs of Bacchylides: the formatting of these texts shows most clearly that scriptio continua is being coordinated with the placements of line-endings that correspond to the ends of cola (Nagy 2000).

Even if the process of reading such texts in scriptio continua was cognitively more difficult than the process of reading the more recent scriptio discontinua as simulated in the printed pages of modern editions, the older way of formatting offered the advantage of reading something that was far closer to the reality of live performance.

Viewed in this light, the device of scriptio continua can be counted as yet another aspect of the overall accuracy and precision of the Greek writing system in representing the reality of Greek speech and song. Maybe it was no "miracle," but it was a most effective device for bringing ancient Greek song and speech back to life for those who listened to it being read back to them out loud.

It can be said that the experience of seeing words run together in scriptio continua impedes not so much the general process of reading but the specific process of "silent reading" (Saenger 1997:11). This term silent reading refers to a way of reading that dispenses with the ancient practice of reading out loud. There has been a long debate over the validity of such a dichotomy, without a clear outcome (Gavrilov 1997). This much is certain, however: from the standpoint of cognitive psychology, the mental process involved in reading out loud requires in its own right an element of "silent reading" - since the sequence of cognition in reading letters one after the other is moved forward by the reader's hearing the actual sequence of what is being sounded out loud. That is because this sequence of letters serially turning into sounds is given meaning by the serial sounding out of words that take shape as the sequence continues, helping the reader keep moving ahead to the finish.

What I just said applies even if the reader mechanically sounds out letters without at first 'recognizing' the meaning of what is being sounded out. For the process of reading out 
loud to be successful, what really matters is that the sequence of letters being read out loud must be 'recognized' ex post facto. The sequence of sounds being read out loud by the reader is what drives the reader's process of 'recognition'. Such is the idea expressed by the word anagignōskein, which means 'read out loud' and, more basically, 'recognize'.

A most telling example of anagignōskein in the sense of 'read out loud' is a passage in the Poetics of Aristotle (1462a12). He is saying that tragoidia 'tragedy', just like epopoiia 'epic', can reveal its inherent characteristics as a genre simply by way of being read out loud, and the word he uses here for 'read $\{421 \mid 422\}$ out loud' is anagignōskein. It is clear that Aristotle really means reading out loud here, not silent reading (Halliwell 1995:138).

A combination of two linked passages in the Poetics helps clarify what Aristotle means here. In the first of these two, Aristotle is contrasting the reading out loud of tragedy with the acting of tragedy by hupokritai 'actors' at a public festival, that is, at an agōn (1450b18-19), and he is making the point that opsis 'spectacle' is not essential for tragedy (1450b19-20). In the second linked passage (1453b3-6), he makes the same point, but this time he adds that tragedy has the power to visualize even without making the audience 'see' (horân) a spectacle but simply by way of having them 'hear' (akouein). From these two linked passages we see that Aristotle accepts the idea that hearing is essential even for the reading of tragedy, not only for the performance of tragedy in theater. And what is being heard is obviously what is being read out loud.

As Aristotle says, visualization is a necessity for tragedy - even when this medium is simply being read out loud instead of being formally performed in theater. And what he is saying here is not just theory. More than that, it is an institutional reality of theater. This reality is demonstrated by the inherent meaning of the ancient Greek word that conventionally refers to the audience of theater. That word is theatès, conventionally translated as 'spectator' and meaning basically the one who sees the spectacle - just as the word for 'theater', theatron, has the basic meaning of the vehicle for seeing the spectacle.

This meaning of theatēs 'spectator' is strikingly exemplified by the wording of the Athenian statesman Kleon in a speech recreated by Thucydides (3.38.4): in this speech, Kleon criticizes the Athenians as theatai men tōn logōn ... akroatai de tōn ergōn 'spectators of words, audiences of deeds'. The speaker's point here is that theater is so much a part of the lives of Athenians that they treat the real things that people say about real things that people do as if all these things were theatrical spectacles. Thus the Athenians become theatai 'spectators' of real things being said as if these things were theatrical lines being delivered by professional performers, and they imagine things done off stage, as it were, by merely hearing these things instead of seeing them for themselves. 
Significantly, the speaker in this passage from Thucydides (3.38.4) starts the wording of his criticism by saying that the Athenians are acting like perverted agonothetai 'arrangers of the competition [agōn]' (kakōs agōnothetoûntes). We have already seen Aristotle use the word agōn 'competition' in referring to a public festival that serves as the venue for the acting of tragedy by hupokritai 'actors', which is an occasion of opsis 'spectacle' (1450b19-20). That agōn is evidently the festival of the City Dionysia in Athens, which was the primary venue for the spectacle of Athenian State Theater. But the speaker in the passage from Thucydides seems to have in mind another agōn as well. That other agōn is the festival of the Panathenaia in Athens, which was the primary venue for another spectacle organized by the Athenian State. And that spectacle has to do with the performance of the Homeric Iliad and Odyssey. $\{422 \mid 423\}$

As we learn from the Aristotelian Constitution of the Athenians (60.1), ten magistrates called athlothetai 'arrangers of the contests [athloi]' were elected every four years to organize the festival of the quadrennial or "Great" Panathenaia, and one of their primary tasks was the management of 'the 'agōn in mousikè' (ton agōna tēs mousikēs). Here the word agōn is used in the specific sense of 'competition', and this use is more basic than the more extended use of the word in the sense of 'festival'. According to Plutarch's Life of Pericles (13.9-11), the Athenian statesman Pericles reformed this competition in mousike when he was elected as one of the athlothetai. It was at this competition that quadrennial performances of the Homeric Iliad and Odyssey took place (Nagy 2002:36, 41-42).

What, then, does the author of the Constitution of the Athenians actually mean when he says mousikêe? In Aristotelian usage, this word mousikē is a shorthand way of saying mousike tekhne, meaning 'craft of the Muses', that is, 'musical craft' in the etymological sense of the word musical. It would be a misreading, however, to think of ancient Greek mousike simply in the modern sense of music, since the 'musical' performers who competed with each other in separate categories at the Panathenaia included not only kitharoidoi 'kithara-singers' and kitharistai 'kithara-players' and aulōidoi 'aulos-singers' and aulètai 'aulos-players' but also rhapsoidoi 'rhapsodes'. At the Panathenaia, these rhapsodes competed with each other in performing the Homeric Iliad and Odyssey. And the performative medium of these rhapsodes in the era of Aristotle was recitative and thus not 'musical' in the modern sense of the word. By recitative I mean (1) performed without singing and (2) performed without the instrumental accompaniment of the kithara or the aulos (Nagy 2002:36, 41-42). In this era, the competitive performances of the Homeric Iliad and Odyssey by rhapsodes at the Panathenaia were 'musical' only in an etymological sense, and the medium of the rhapsode was actually closer to what we call 'poetry' and farther from what we call 'music' in the modern sense of the word. Still, the fact remains that the Homeric performances of rhapsodes were an integral part of what was called the 'agōn [competition] in mousike'.

Plato's dialogue Ion is about such a rhapsode. At the start of the dialogue, Ion of Ephesus has just arrived in Athens in order to compete with other rhapsodes for first prize at the 
festival of the Panathenaia (Ion 530b). Plato's wording makes it explicit that the occasion for performances of Homeric poetry at the Panathenaia was in effect an agōn or 'competition' among rhapsodes, and that the agonistic craft of the rhapsodes was included under the general category of mousike (530a).

This mousike of the rhapsode at the festival of the Panathenaia was the grandest of spectacles, rivaling even the spectacle of actors acting tragedy at the festival of the City Dionysia. Aristotle gives a sense of this grand rivalry toward the end of Book I of the Poetics. In considering the question whether tragedy or epic is the best of all genres of poetry, he concludes that tragedy could easily be considered as good as epic - if it were not for all the distractions of theatricality - such as the element $\{423 \mid 424\}$ of kinesis 'motion' involved in acting (1461b30). Then he makes tragedy more competitive by conceding that this genre cannot really be divorced altogether from the element of motion (1462a9-10). The concession is transparent, since Aristotle knows full well that motion is inherent in tragedy. After all, one of the basic features of tragedy is the chorus, which of course dances as well as sings (again, 1462a9-10). But then Aristotle dispenses with his own concession by asserting that tragedy does not even need the element of motion in order to be competitive with epic. Even if tragedy is deprived of motion, he says, it is still competitive with epic. All that is needed is simply to read it out loud (anagignōskein: 1462a11-12). In this context, it is understood that epic too is most competitive. In the case of epic as well, all that is needed is simply to read it out loud.

Having made his point about the reading out loud of epic as well as tragedy, Aristotle now lets the two genres compete with each other - but this time without putting any restrictions on tragedy. This time, he lets tragedy keep its theatrical elements. Restrictions removed, tragedy can now compete with epic in meter (1462a14) and in what Aristotle calls mousike and opsis (1462a15-16).

We have already observed the meaning of mousike, while the meaning of opsis as 'spectacle' is self-evident. But the combination of these two words here in the Poetics has troubled modern editors. Some even worry whether there has been a corruption of textual transmission. But the wording is sound and consistent if it refers to the grand spectacle of epic performance at the Panathenaia, which as we have seen represents the very best in the craft of mousike. By the time Aristotle speaks of mousike and opsis, he has reached a point of accepting the element of spectacle inherent in epic performance, just as he has accepted the element of spectacle inherent in tragic performance. Here is the only place where we see the word mousikē in Aristotle's Poetics. And we know from elsewhere, including Plato's Ion and the Aristotelian Constitution of the Athenians, that this word mousike is linked closely to the craft of rhapsodes who perform the Homeric Iliad and Odyssey at the festival of the Panathenaia.

Conceding that spectacle is inherent in both epic and tragedy, Aristotle goes on to say that both genres can be spectacular even without their having to show any spectacle to their 
audiences. The spectacle can happen simply by way of hearing tragedy and epic as they are being read out loud. This way, a distinctive vividness still comes through, which is a modified form of spectacle. This vividness is made possible by way of reading out loud, which is in turn a modified form of performance. Aristotle says all this explicitly about tragedy. Here is a medium that shows its true 'vividness' (to enarges) even when it is simply read out loud as well as when it is performed (1462a17-18: kai en tēi anagnōsei kai epi tōn ergōn).

The wording here is most significant. Aristotle is setting up a parallel between the performance of tragedy in its formal setting, as expressed by the idiom epi tôn ergōn 'in performance' (Janko 1987:156), and the 'reading out loud' of tragedy in a modified setting, as expressed by the noun anagnōsis, derived from anagignōskein. \{424|425\} Aristotle's formulation leaves it understood that the same parallel applies to that other spectacular genre, epic. In that case, he is saying it implicitly - that there is also a parallel between the performance of epic in its formal setting and the anagnōsis 'reading out loud' of epic in a modified setting.

As we saw earlier, the formal settings for the performances of epic and tragedy are the Panathenaia and the City Dionysia respectively. And now we see that both settings are actually understood as theatrical by Aristotle himself. He says that epic as well as tragedy is conventionally performed in front of theatai 'spectators' (1461b28, 1462a1). And, though he adds that the 'spectators' of epic are far less of a problem for him than the 'spectators' of tragedy, since the element of theatricality in the performance of epic is far less pronounced than it is in the performance of tragedy (1461b36-62a4), he nevertheless goes on to say that skhèmata 'poses' (1462a2) and other 'visual signs' or sêmeîa (1462a6) characterize not only the actors of tragedy but even the professional performers of epic called rhapsodes or rhapsoidoi. In this context, he actually uses the verb rhapsoideîn 'perform rhapsodically' (1462a6), citing as an example a rhapsode called Sosistratos who had a reputation for performing in an overly theatrical way (1462a7). In the end, Aristotle thinks that rhapsodes are just as theatrical as actors. Since rhapsodes, like actors, engage in theatrical poses and other such visual effects, it is clear they too are in effect practicing the craft known as hupokritike (1462a5), that is, the craft of hupokritai 'actors'.

For Aristotle, however, the point remains that poietike, the craft of poets, should be kept distinct from this craft of actors (1462a4-5). As we have seen, he thinks that the craft of poets should be divorced from theatricality. But even his usage of the word theatess 'spectator' betrays the impossibility of such a divorce. Aristotle himself uses this word theatès to refer to the audience of epic as well as tragedy. We have already seen him speak of theatai 'spectators' with reference to an audience listening to the performance of a rhapsode (1462a1-6). We see the same pattern of wording in Plato's Ion (535e), where the same word theatēs 'spectator' is used with reference to a hypothetical member of an audience listening to a rhapsode performing the Iliad and Odyssey at the festival of the Panathenaia in Athens. The speaker is 
Plato's Socrates, who makes no distinction in this context between the audiences of a rhapsode and the audiences of an actor, specified here as a hupokritēs (536a).

This pattern of associating tragedy with epic and epic with tragedy reflects an institutional reality. The genre of epic, as performed at the festival of the Panathenaia, actually shaped and was shaped by the genre of tragedy as performed at the festival of the City Dionysia. In Athens, ever since the sixth century BCE, these two genres were "complementary forms, evolving together and thereby undergoing a process of mutual assimilation in the course of their institutional coexistence" (Nagy 1996a:81).

The parallelism between epic as performed by rhapsodes at the Panathenaia and tragedy as performed by actors at the City Dionysia is evident at the very beginning of the Poetics of Aristotle (1447a13-15). We see there the genres of poetry listed in the following order: epic or epopoiia (which means literally 'the making of epos'), tragedy, comedy, dithyramb, lyric accompanied by aulos 'reed', and lyric accompanied by kithara 'lyre'. All these genres, as listed by Aristotle at the beginning of the Poetics, correspond to genres actually performed at the two major festivals of the Athenians: (1) the Panathenaia, featuring epic accompanied by no instrument, lyric accompanied by aulos, lyric accompanied by kithara; and (2) the City Dionysia, $\{425 \mid 426\}$ featuring tragedy, comedy, dithyramb, and satyr drama (Nagy 1996a:81-82; 1999:27; Rotstein 2004). In Aristotle's listing, he ostentatiously pairs the genre of epic with the genre of tragedy (the wording is epopoiia ... kai hè tēs tragōidias poiēsis, which means literally 'the making of epos and the making of tragedy'). Elsewhere, Aristotle says that he views these two particular genres, epic and tragedy, as cognates (Poetics 1449a2-6). In the works of Plato as well, epic is viewed as a cognate of tragedy: more than that, Homer is represented as a proto-tragedian (Theaetetus 152e; Republic 10.595c, 598d, 605c, 607a).

What the genres of poetry as listed at the beginning of the Poetics all have in common is that they are forms of mimessis 'reenactment', as Aristotle says explicitly (1447a16). This commonality needs to be viewed in the light of the fact that all these genres are also forms of performance. As we just saw, these genres of poetry are actualized as poetry by way of being performed at one or the other of the two premier state festivals of the Athenians, the Panathenaia or the City Dionysia. In the case of epic and tragedy, these two particular genres are in fact the premier forms of performance at those two festivals respectively.

In the Poetics, then, the concept of mimessis as 'reenactment' necessarily involves the performance of poetry as well as its composition. In fact, the semantic history of the word mimessis in the primary sense of 'reenactment' and even in the secondary sense of 'representation' or 'imitation' confirms the inclusion of performance as well as composition in its basic meaning (Nagy 1996a:59-103). 
Aristotle may prefer to concentrate on those aspects of poetry that have to do with composition, but he cannot ignore the aspects of performance. That is why he has to evaluate in terms of mimessis the relative merits of epic and tragedy toward the end of Book I of the Poetics, where he confronts the question of deciding which of these two premier genres of poetry, epic or tragedy, is superior to the other. He formulates his question this way: 'which form of mimēsis is better, the epic or the tragic?' (1461b26: poteron de beltiōn hēepopoiikē mimēsis $\bar{e} h \bar{e}$ tragikē). He is forced to ask his question this way because he cannot ignore the formal performance of epic and tragedy at the festivals of the Panathenaia and the City Dionysia respectively. Still, Aristotle prefers to confront and analyze this element of performance in a modified form. This modified form of performance is by way of anagnōsis, that is, by way of hearing the text being read out loud. As we saw earlier, Aristotle in the Poetics says that the performing of tragedy and epic in this modified form of performance, anagnōsis 'reading out loud', is the equivalent of performing them in their formal setting, epi tōn ergōn 'in performance' (1462a17-18: kai en tēi anagnōsei kai epi tōn ergōn).

As far as Aristotle was concerned, this modified form of performance gets it right, as it were. Simply to read the text out loud and not to act it as actors and rhapsodes do makes it possible for the listener to grasp the essence of the poetry without getting distracted by its theatricality. This way, those who hear poetry being read out loud can be as objective as possible in analyzing the true $\{426 \mid 427\}$ nature of poetry. Here I find it relevant to cite an ancient anecdote about Aristotle: the story has it that his teacher Plato gave Aristotle the sobriquet anagnōstēs, that is, 'the one who reads out loud' (Vita Marciana, Aristotle F $428.2 \mathrm{ed}$. Rose; Nagy 1996a:149).

This same word anagnōstēs is attested with reference to slaves trained to read texts out loud to copyists for the purpose of mass-producing copies of a book (Nepos Life of Atticus 13.3). Such a context implies that the text that is being read out loud needs to be a model text (Nagy 1996a:149-150).

The question remains, how to establish such a model text in the first place? In terms of the Greek language, the basic procedure for establishing a model text is to make an ekdosis 'edition' by way of a process of cross-checking that leads to the diorthōsis 'correcting' of the text. And the word that refers to this process of cross-checking is paranagignōskein, which can be translated as 'read out loud for cross-checking'.

Here is an example. It comes from the Explicit to the commentary of Eutocius of Ascalon (sixth century CE) on Book I of Archimedes On Sphere and Cylinder: Eutokiou Askalionitou hupomnēma eis to prōton tōn Arikhimēdous peri sphairas kai kulindrou, ekdoseōs paranagnōtheisēs tōi Milēsiōi mēkhanikōi Isidōrōi hēmeterōi didaskalōi '[here is] the commentary [hupomnēma] of Eutocius of Ascalon to the first volume of the works of Archimedes On Sphere and Cylinder, and 
the ekdosis had been read out loud to the Milesian engineer Isidore, my teacher, for crosschecking [paranagignōskein]' (ms. Laurentianus 28.4; Cameron 1990.103-107).

My interpretation of paranagignōskein here, 'read out loud for cross-checking', needs further comment (in what follows, I correct what I say in Nagy 1996a:175-176n83, thanks to Davidson 2001:410n19). Such contexts of paranagignōskein indicate that the text that is being read out loud is a model text in the making, that is, it is a text that becomes a model through the actual process of cross-checking and correcting.

I highlight a detail in the wording of the passage we have just considered. Here the editor of the text of Archimedes (third century BCE) is Isidore of Miletus (sixth century CE). This 'Milesian Engineer', along with Anthemius of Tralles, was commissioned by Justinian in $532 \mathrm{CE}$ to design and build the new Hagia Sophia. The model text that Isidore is editing is in this case the actual text of Archimedes that is being read back to Isidore for cross-checking and correction. Such a process of cross-checking may also involve reading from - or remembering from - parallel texts, leading to corrections and, ultimately, approval by the editor.

Another striking example comes from the heading of Book 3 of the commentary of Theon of Alexandria (fourth century CE) for the Almagest of Ptolemy (second century CE): Theōnos Alexandreōs eis to triton tēs mathēmatikēs Ptolemaiou Suntaxeōs hupomnēma ekdoseōs paranagnōstheisēs tēi philosophōi thugatri mou Hupatiāi 'The commentary [hupomnēma] of Theon of Alexandria to the third volume of the mathematike Suntaxis of Ptolemy, and the ekdosis had been read out loud to my philosopher daughter Hypatia for cross-checking [paranagignōskein]' (ms. Laurentianus 28.18; Cameron 1990.106).

The role of Theon's learned daughter Hypatia can be better understood in light of the formula describing the role of Theon himself, as we read in the headings to Books 1 and 2 of Theon's commentary on Ptolemy's Almagest: Theōnos Alexandreōs tēs par autou gegenēmenēs ekdoseōs eis to prōton / deuteron tēs Suntaxeōs Ptolemaiou hupomnēma 'The commentary [hupomnēma] of Theon of Alexandria of the edition [ekdosis] made by him of the first / second volume of the Suntaxis of Ptolemy' (Cameron 1990.111).

Just as the father edited Books 1 and 2 of Ptolemy's Almagest, so also the daughter edited Book 3: for the first two books, Theon produced both the edition and the commentary, but for the third he produced only the commentary while Hypatia produced the edition. As we see in the more expanded wording that describes the contribution of the daughter, the actual process of editing involved the reading out loud of the text to the editor. This process is mentioned explicitly only when the person who produced the commentary or hupomnema is different from the person who produced the edition or ekdosis.

Unlike the roles of Isidore and Hypatia, who produced only the ekdosis but not the hupomnema for their respective texts, the role of Theon is directly comparable to that of 
Aristarchus (second century BCE), the master editor who produced both an ekdosis 'edition' and a hupomnema 'commentary' for the Homeric Iliad and Odyssey (Nagy 2004a:85-86). He too, like Isidore and Hypatia, must have edited the text by having it read out loud to him for the purpose of cross-checking. That is, the Homeric base text was read out loud to Aristarchus as part of the editorial procedure of his diorthosis 'correcting'. In the Homeric scholia, we find two references to this procedure. They both involve a man called Posidonius, who is described as the anagnōstēs 'reader' for Aristarchus (scholia A for Iliad 17.75a / 6.511a). The process of crosschecking leads to diorthōsis 'correction' and, ultimately, approval, so that the edited text - in this case, of Homer - may become the model text (Nagy 2008/2009).

Aristotle himself was already engaged in this kind of editing of the text of Homer. We know for a fact that he was very much engaged in research on problems of Homeric textual transmission, and there is considerable evidence linking him with the very concept of diorthōsis (Nagy 1996a:121). For example, he uses the verb diorthoûn 'correct' and the abstract noun diorthosis 'correcting' in the sense of provide the right interpretation of a difficult text, or provide the right solution to a question (erötēma), as in Sophistici Elenchi (chapters 18 and 19). In the same work, we even find the expression ton Homeron enioi diorthoûntai 'some people correct [diorthoûn] Homer' (Sophistici Elenchi 166b3), with reference to an alternative reading that is being proposed for a passage in the Iliad (23.328). To choose such an alternative reading is to 'correct', as it were, the received text of Homer.

It is evident that such 'corrections' were envisioned as markings in the margins or diacritics in the text. For the sophistic tradition in general and for Aristotle in particular, the format of diorthōsis was distinctly a matter of marginalia. A case in point is Aristotle's mention of a parasēmon 'marginal mark' (Sophistici Elenchi 177b) in a context of discussing a variant accentuation (and breathing). We may note as well the following description of a copy of Homer owned by Alexander the Great: 'it is reported that there was a diorthosis of the poetry of Homer, called "the one from the narthexx," when Alexander with Callisthenes and Anaxarchus went over it and made some marks [sēmeîa] on it' (Callisthenes FGH $124 \mathrm{~T} 10$ by way of Strabo 13.1.27 C594). Elsewhere, we hear that this narthēx edition of Homer resulted from a diorthōsis made by Aristotle himself (Aristotelous diorthōsantos: Plutarch Life of Alexander 8.2). The Vita Marciana speaks of Aristotle's ekdosis of the Iliad, which he gave to Alexander (Aristotle Fragments p. 427.5 ed. Rose).

We have seen that the practice of reading texts out loud for cross-checking, as conveyed by the word paranagignōskein, could serve the purpose of establishing a model text, that is, a would-be archetype for copyists. Now we will see that such a model for copyists could also become a model for performers, that is, a model performance or script. There is in fact an attested piece of testimony that speaks explicitly about the establishment of such a model for the classics of tragedy in Athens. This testimony, which comes from the Lives of the Ten Orators (attributed to Plutarch), has to do with an event that took place in the era of Aristotle. some 
time around the third quarter of the fourth century. According to the Lives of the Ten Orators (841f), the statesman Lycurgus of Athens initiated reforms in the performance traditions of State Theater in Athens, legislating an official "State Script" for the tragedies of three poets and three poets only, Aeschylus, Sophocles, and Euripides. Lycurgus introduced a law requiring that the Athenians erect bronze statues of Aeschylus, Sophocles, and Euripides, and that the State make official the texts of the tragedies of these three poets in the following way: tas tragōidias autōn en koinōi grapsamenous phulattein kai ton tēs poleōs grammatea paranagignōsein tois hupokrinomenois, ouk exeînai gar autas hupokrinesthai '...that they [that is, the Athenians] were to transcribe their tragedies [that is, the tragedies of Aeschylus, Sophocles, and Euripides] and keep them under control in common possession, and that the recorder [grammateus] of the city was to read them out loud, for cross-checking [paranagignōskein], to those acting in the tragedies, for otherwise it was not possible to act them [that is, the tragedies]' ("Plutarch" Lives of the Ten Orators 841f).

Although this passage leaves unanswered many questions that arise concerning the interplay of script and performance in tragedy as acted in the Athenian State Theater of Aristotle's time, it makes one thing quite clear: the actors of tragedy were bound to an Athenian "State Script."

Quintilian (Institutio oratoria 10.1.66) gives further testimony about such an Athenian "State Script": $\{427 \mid 428\}$ tragoedias primus in lucem Aeschylus protulit, sublimis et grauuis et grandilocus saepe usque ad uitium, sed rudis in plerisque et incompositus; propter quod correctas eius fabulas in certamen deferre posterioribus poetis Athenienses permisere; suntque eo modo multi coronati 'the first to bring out tragedies was Aeschylus - sublime, severe, and often grandiloquent to a fault, but unpolished in many ways and disorganized; on account of which the Athenians allowed later poets to introduce into dramatic competitions the corrected versions of his dramas, and in this way many of these later poets won the crown of victory'. We may note with special interest the expression correctas, which is analogous to the concept of diorthosis 'correcting', which as we have seen is linked to the custom of paranagignōskein 'read out loud for cross-checking' (Nagy 1996a:174-175).

There is evidence for other such customs as well. Even in earlier times, the Athenian State exerted its control over the production of drama by way of instituting formal occasions for reading it out loud. A piece of evidence is the expression drama anagignōskein 'read out loud the drama', attested in the scholia for the Clouds of Aristophanes (510). This expression evidently refers to the custom of holding a formal audition for the dramas proposed for production at the dramatic festivals. The dramas of each dramatist, in competition with other dramatists, were subject to acceptance or rejection by the archon in charge of the given dramatic festival (arkhōn epōnumos for the City Dionysia, arkhōn basileus for the Lenaia). As we see from an allusion to this custom in Plato's Laws (7.817d), the archon who presided at the audition determined whether the State would or would not grant the authorization of a chorus 
to be trained for the production of the dramas proposed by the dramatists (Pickard-Cambridge 1968:84).

Relevant to such customs is a passage from the Frogs of Aristophanes (originally produced in $405 \mathrm{BCE}$ ), where the god Dionysus reminisces that he was once anagignōskōn 'reading out loud' to himself (verses 52-53: anagignōskonti moi ... pros emauton) the Andromeda of Euripides (originally produced in $413 / 2 \mathrm{BCE}$ ). Given the self-referential jokes, throughout the Frogs, about Dionysus as god of Athenian State Theater, the self-representation of Dionysus as reading tragedy out loud neither to actors nor to an archon but rather to himself may be interpreted as a comic reference to a performance of the State Script by the god of script himself (Nagy 1996a:176n86).

The idea of a script as a State Script is old, going all the way back to the age of the tyrants of Athens, the Peisistratidai, who controlled Athens in the sixth century BCE (Nagy 1990a:6\$\$19-20). Retrospectively, the Athenian democracy looks at this idea as dangerous unless that script can be read out loud. That is because the process of reading out loud is a speech-act, like performance itself, and it is public, not private.

In contrast with reading out loud, the process of silent reading is decidedly not a speech-act: thus for example in the Hippolytus of Euripides, the figure of Theseus, when he reads silently the tablet left behind by the dead Phaedra, does not activate the force of these words until he sums up their contents publicly to the chorus (856-886). Such silent reading is symptomatic of the tyrant's power to control the performance of a composition. In the Knights of Aristophanes (originally produced in $424 \mathrm{BCE}$ ), we see the image of a kibötos 'box' that stores hidden oracles (1000) that can be taken out by the demagogue Kleon and read out loud to Demos (1011), but we know that the reader of the oracles also has the power to read ahead, silently, and then interpret his reading, with a voice that is accepted as the authority of the oracles (again 115-146). In these images of storing oracles in a box and then taking them out either to be read out loud to Demos or, alternatively, merely to be interpreted, we see the ultimate metaphor for the control of performance by the State (Nagy 1990:6\$\$50-51). From the standpoint of the democratic State, by contrast, reading out loud is public and thus democratic, while reading silently is private and undemocratic.

So far, we have considered only those genres that are realized in performance. The most prominent of these are epic, tragedy, and comedy. As we have seen, these and all the other genres listed at the beginning of Aristotle's Poetics are in fact realized in performance. But what about genres that are not performed, such as $\{428 \mid 429\}$ history - or the Platonic dialogue? Even in these cases, the relevant texts are performative if not performable.

Let us take for example the History of Herodotus, who calls his medium an apodeixis (Ionic apodexis) 'making public' at the very beginning of his composition. Anyone in the History 
who is pictured as performing any ergon 'deed' that is worth being memorialized by history can be said to be making that deed public, as expressed by the verb apodeiknusthai 'make public' corresponding to the noun apodeixis 'making public'. There are numerous examples of this combination of ergon and apodeiknusthai in the History, and in each case we may translate as 'perform a deed'. That is because each such deed is made public by the publicity that is history (Nagy 1990:8§5).

By contrast, the text of the history composed by Thucydides is not made public. When he speaks of his History as a ktêma ... es aiei, 'a possession for all time', he is contrasting his own private possession of knowledge about world affairs with the making public of such knowledge, which would be conditioned by the vicissitudes of public performance - and which he describes as a 'competitive effort [agōnisma] meant for hearing in the here and now' (1.22.4). His own knowledge, as reflected even in the speeches that he reenacts in writing, is not to be performed. To that extent, the medium of Thucydides is private and undemocratic (Nagy 1990:8\$7). Still, it is performative, since it shows how speeches are performed. Similarly in the Phaedo of Plato, the dialogue with Socrates is performative, since Socrates shows how dialogues are performed. Each time there is dialogue, the word or logos comes back to life (Loraux 1989).

\section{Further Reading}

Bauman 1977 analyzes various types and degrees of interaction between performance and composition as combined aspects of oral traditions. Guillén 1993 situates the study of oral traditions within the academic discipline of Comparative Literature. Lord 1995 (a posthumous publication) offers a sustained rebuttal of critics who insist on the inferiority of "orality" to literacy. Bausinger 1980 gives a historical study of culturally and ideologically determined distinctions between "high art" and "low art," as associated respectively with literary and oral traditions. On orality and literacy, there is a general survey, with bibliography, in Nagy 2001.

Martin 1989 presents a case study of oral poetic sub-genres embedded within the "super-genre" of Homeric poetry, with special attention to applications of "speech-act" theory. Bakker 1997 examines syntactical patterns typical of oral traditions and even of "everyday" speech as preserved in the text of the Homeric poems. Graziosi 2002 and Nagy 2004 analyze myths about Homeric performance in terms of Homeric reception.

Examining the anthropology of reading as a cognitive process, Svenbro 1993 analyzes the ancient Greek mentality of equating the activity of reading out loud with the act of lending one's voice to the letters being processed by one's eyes. Nagy 2001 examines phenomena of literacy that defy universalization, such as the practice of scriptio continua in archaic, classical, and post-classical Greek, to be contrasted with the practice of leaving spaces for wordboundaries, as in the traditions of writing Hebrew. Gavrilov 1997 investigates the cultural and cognitive variables of "silent reading" and reading out loud, concluding that a mutually exclusive dichotomy is untenable. 


\section{Bibliography}

Bakker, E. J. 1997. Poetry in Speech. Orality and Homeric Discourse. Ithaca, NY.

Bauman, R. 1977. Verbal Art as Performance. Prospect Heights, IL.

Bausinger, H. 1980. Formen der "Volkspoesie." 2nd ed. Berlin.

Burgess, J. S. 2004. "Performance and the Epic Cycle." Classical Journal 100:1-23.

Cameron, A. 1990. "Isidore of Miletus and Hypatia: On the Editing of Mathematical Texts." Greek, Roman and Byzantine Studies 31:103-127.

Davidson, O. M. 2001. "La 'publication' des textes arabes sous forme de lectures publiques dans les mosquées.” Des Alexandries. Vol. 1, Du livre au texte (ed. L. Giard and Ch. Jacob) 401411. Paris.

Foley, J. M. 1985. Oral-Formulaic Theory and Research: An Introduction and Annotated Bibliography. New York.

Gavrilov, A. K. 1997. “Techniques of Reading in Classical Antiquity.” Classical Quarterly 47:56-73.

Gelb, I. J. 1952. A Study of Writing. Chicago. 2nd ed. 1963.

http://www.questia.com/library/book/a-study-of-writing-the-foundations-ofgrammatology-by-i-j-gelb.jsp.

Gernet, L. 1983. Les Grecs sans miracle (ed. R. Di Donato). Paris.

Graziosi, B. 2002. Inventing Homer: The Early Reception of Epic. Cambridge.

Guillén, C. 1993. The Challenge of Comparative Literature. Harvard Studies in Comparative Literature 42. Cambridge, MA.

Halliwell, S., ed. and trans. 1995. Aristotle: Poetics. Cambridge, MA.

Householder, F. W., and G. Nagy. 1972. Greek: A Survey of Recent Work. Janua Linguarum, Series Practica 211. The Hague. Revised ed. by Nagy 2008.

Janko, R., trans. 1987. Aristotle Poetics I. Indianapolis, IN.

Loraux, N. 1989. "Therefore, Socrates is immortal." Fragments for a History of the Human Body II (ed. M. Feher, R. Naddaff, and N. Tazi) 13-45. New York.

Lord, A. B. 1960 / 2000. The Singer of Tales. Harvard Studies in Comparative Literature 24. 
Cambridge, MA. 2nd ed., with new Introduction, by S. Mitchell and G. Nagy 2000.

--_. 1986. "The Merging of Two Worlds: Oral and Written Poetry as Carriers of Ancient Values." Oral Tradition in Literature: Interpretation in Context (ed. J. M. Foley) 19-64. Columbia, MO.

-_-. 1991. Epic Singers and Oral Tradition. Ithaca, NY.

---. 1995. The Singer Resumes the Tale (ed. M. L. Lord). Ithaca, NY.

Martin, R. P. 1989. The Language of Heroes: Speech and Performance in the Iliad. Ithaca, NY.

Mitchell, S., and G. Nagy. 2000. Introduction to the Second Edition. In Lord 2000:vii-xxix.

Nagy, G. 1990. Pindar's Homer: The Lyric Possession of an Epic Past. Baltimore. Revised ed. 1994.

-- . 1996a. Poetry as Performance: Homer and Beyond. Cambridge.

--—. 1996b. Homeric Questions. Austin.

- - . 1999. "Epic as Genre." Epic Traditions in the Contemporary World: The Poetics of Community (ed. M. Beissinger, J. Tylus, and S. Wofford) 21-32. Berkeley and Los Angeles.

---. 2000. "Reading Greek Poetry Aloud: Evidence from the Bacchylides Papyri." Quaderni Urbinati di Cultura Classica 64:7-28.

-_-. 2001. "Orality and Literacy." Encyclopedia of Rhetoric (ed. T. O. Sloane) 532-538. Oxford.

-- . 2002. Plato's Rhapsody and Homer's Music: The Poetics of the Panathenaic Festival in Classical Athens. Cambridge, MA and Athens.

---. 2003. Homeric Responses. Austin.

-- - 2004a. Homer's Text and Language. Urbana, IL.

-_-. 2004b. "L'aède épique en auteur: la tradition des Vies d'Homère." Identités d'auteur dans l'Antiquité et la tradition européenne (ed. C. Calame and R. Chartier) 41-67 Grenoble.

-- . 2008. Greek: An Updating of a Survey of Recent Work. Updated edition of Householder and Nagy 1972:15-70. Center for Hellenic Studies. http://chs.harvard.edu.

-- - 2008/2009. Homer the Classic. Cambridge, MA and Washington, DC. The 2008 online version is available at http://chs.harvard.edu.

- - 2009/2010. Homer the Preclassic. Berkeley and Los Angeles. The 2009 online version is 
available at http://chs.harvard.edu.

Oesterreicher, W. 1993. "Verschriftung und Verschriftlichung im Kontext medialer und konzeptioneller Schriftlichkeit." Schriftlichkeit im frühen Mittelalter (ed. U. Schaefer) 267292. Tübingen.

Parry, M. 1971. The Making of Homeric Verse: The Collected Papers of Milman Parry (ed. A. Parry). Oxford.

Pickard-Cambridge, A. 1968. The Dramatic Festivals of Athens. Revised 2nd ed. by J. Gould and D. M. Lewis. Oxford.

Rotstein, A. 2004. "Aristotle, Poetics 1447a13-16 and Musical Contests." Zeitschrift für Papyrologie und Epigraphik 149:39-42.

Saenger, P. 1997. Space Between Words: The Origins of Silent Reading. Stanford.

Saussure, F. de. 1916. Cours de linguistique générale. Critical ed. by T. de Mauro 1972. Paris.

Svenbro, J. 1993. Phrasikleia: An Anthropology of Reading in Ancient Greece. Trans. J. Lloyd. Ithaca, NY. 